\title{
Polymorphism rs11465553 in the Interleukin-17F Gene in Serbian Patients with Psoriasis and Healthy Controls
}

\author{
Svetlana POPADIĆ ${ }^{1,2 *}$, Zorica RAMIĆ ${ }^{3}$, Ljiljana MEDENICA ${ }^{1,2}$, \\ Vera PRAVICA 3 , Dušan POPADIĆ 3 \\ ${ }^{1}$ Department of Dermatovenereology, School of Medicine, University of Belgrade, Belgrade, Serbia \\ ${ }^{2}$ Clinic of Dermatovenereology, Clinical Center of Serbia, Belgrade, Serbia \\ ${ }^{3}$ Institute of Microbiology and Immunology, School of Medicine, University of Belgrade, Belgrade, Serbia \\ ${ }^{*}$ Correspondence: Svetlana Popadić, E mail: spopadic@med.bg.ac.rs \\ DE GRUYTER \\ UDK 616.517-092:577.2

\section{OPEN}

\begin{abstract}
We examined single nucleotide rs 11465553 polymorphism in the interleukin-17F gene causing valine to isoleucine substitution at the position 155 in the third exon of IL17F gene in Serbian patients with psoriasis and healthy blood donors. For the first time we found rs $11465553 \mathrm{G}$ (valine) and A (isoleucine) allele frequency in healthy Serbian population and in psoriasis patients, but without statistically significant difference between the two groups.
\end{abstract}

\section{Key words}

Interleukin-17; Polymorphism, Single Nucleotide; Psoriasis; Arthritis, Psoriatic; Blood Donors; Valine; Isoleucine; Real-Time Polymerase Chain Reaction

$P_{\mathrm{in}}^{\mathrm{sin}}$ soriasis vulgaris (PsV) is a common chronic inflammatory skin disease affecting approximately $2-4 \%$ of the general population, with significant ethnic and geographic variations. Psoriasis is characterized by cutaneous inflammation and keratinocyte hyperproliferation that may be accompanied by severe complications, such as psoriatic arthritis (PsA), a debilitating inflammatory joint disease (1). Based on the time of onset, psoriasis is divided into type 1 early onset psoriasis (disease starts before the age of 30 ) and type 2 - late onset psoriasis, which appears later in life (2). Type 1 psoriasis affects approximately $65 \%$ of psoriasis patients and it is usually associated with progressive course of the disease. Disease severity and activity is usually measured by Psoriasis Area and Severity Index (PASI) $(3,4)$.

Substantial evidence supports a central role of interleukin-17 (IL17) - producing $\mathrm{T}$ cells (Th17) dysregulation resulting in psoriasis (1). The recent development of biological drugs that target cytokines secreted by Th17 has confirmed the importance of this subpopulation in the initiation/maintenance of inflammatory processes in psoriatic skin and yielding potent therapies in the treatment of PsV (5). Induction of Th17 response leads to release of proinflammatory IL17 family cytokines such as IL17A and IL17F from Th17 and $\gamma \delta$ T-cells which further influence keratinocyte activation (6). IL17F induces release of proinflammatory and neutrophilmobilizing cytokines such as IL-6 and IL-8 (7), which enhance skin inflammatory pathways and further development of skin lesions in psoriasis (8). IL17F in psoriatic lesions is produced by neutrophils and mast cells (9).

Previous studies have shown that psoriasis belongs to so-called complex genetic diseases, in which the risk of inheriting the disease appears to be determined by interaction of multiple genes. IL $17 F$ is a gene located on the short arm of the chromosome 6 (6p12) and represents an interesting area in the investigation of chronic inflammation pathways. Some single nucleotide polymorphisms (SNPs) in IL17F, 
such as rs763780 T/C which represents a substitution of histidine at position 161 to arginine in $I L 17 F$, are associated with ulcerous colitis, a typical Th17 disease (10), but also bronchial asthma, a typical Th2 disease (7). However, association of SNPs in ILI7F and PsV susceptibility is still unclear due to small number of studies and insufficient data. A recent study in Japan showed that rs 763780 polymorphism is not associated with an increased susceptibility to PsV (11).

Bearing in mind the important role of IL17 cytokines in psoriasis, ethnic differences, and the lack of clearly defined polymorphisms of ILITF, which may be considered biomarkers of PsV susceptibility, we investigated whether rs $11465553 \mathrm{G} / \mathrm{A}$ polymorphism, causing valine to isoleucine substitution at the position 155 in the $I L 17 F$, can be used as a potential biomarker of susceptibility to PsV.

\section{Patients and methods}

The study included 130 patients with PsV treated at the Clinic of Dermatovenereology, Clinical Center of Serbia. Demographic and clinical data are given in Table 1. Patients were classified according to the time of PsV onset, while presence of PsA was confirmed by an experienced rheumatologist. Blood samples from 305 healthy blood donors were obtained from the National Blood Transfusion Institute of Serbia. Informed written consent was obtained from all individuals before blood sampling, and this study was approved by the ethics committees of the School of Medicine, University of Belgrade, Clinical Centre of Serbia and National Blood Transfusion Institute in accordance with Helsinki Declaration.
Genomic DNA was isolated from peripheral blood EDTA samples, using GeneJET whole blood genomic DNA purification mini kit (Fermentas Thermo Fisher Scientific Inc, Vilnius, Lithuania). Detection and analysis of IL17F polymorphism (rs11465553), was performed with commercial TaqMan genotyping assay (PE, Applied Biosystems Inc, Foster City, CA., USA.) with Maxima Probe qPCR Master Mix, (Fermentas Thermo Fisher Scientific Inc, Vilnius, Lithuania) using the RealPlex ${ }^{2}$ (Eppendorf AG, Hamburg, Germany) under cycling conditions as recommended by manufacturer of oligonucleotide mixture.

Hardy-Weinberg equilibrium of rs11465553 $I L 17 F$ genotypes was tested by online calculator available at http://www.oege.org/software/hwemr-calc.shtml. Comparison between genotype and allele frequencies in different groups was performed using the Pearson Chi-square test or Fisher's exact probability test, when applicable.

\section{Results}

Genotype frequencies were in Hardy-Weinberg equilibrium for healthy controls and patients. $\mathrm{X}^{2}$ values were 3.15 for healthy blood donors and 0.07 for patients $(<3.84$ which is a threshold of significance at the level of 0.05 ) (Table 2), suggesting that a sufficient number of subjects were analyzed in each group, and that $G$ and $A$ alleles were inherited in accordance with Mendel's laws. The results of genotyping for patients with $\mathrm{PsV}$ and healthy controls along with $\mathrm{p}$ values, odds ratios and confidence intervals are presented in Table 3. The allele frequencies and genotype distribution for rs11465553 ILITF polymorphism

Table 1. Characteristics of $130 \mathrm{PsV}$ patients

\begin{tabular}{lcc} 
& Number & Percentage \\
Gender (male/female) & $93 / 37$ & $71.3 / 28.7$ \\
\hline Type 1 psoriasis (age at onset $<30$ y) & 62 & 48.1 \\
\hline Type 2 psoriasis (age at onset $>30$ y) & 68 & 51.9 \\
\hline Psoriatic arthritis & 26 & 20.2
\end{tabular}

PsV, Psoriasis vulgaris; y, years 
Table 2. Hardy-Weinberg equilibrium for rs11465553 genotype frequencies

\begin{tabular}{|c|c|c|c|c|}
\hline \multicolumn{2}{|c|}{ IL17F rs11465553 } & Controls & PsV & Total \\
\hline \multirow{3}{*}{ Genotype } & GG & 279 & 124 & 403 \\
\hline & GA & 24 & 6 & 30 \\
\hline & $\mathrm{AA}$ & 2 & 0 & 2 \\
\hline \multicolumn{2}{|c|}{ Total } & 305 & 130 & 435 \\
\hline \multicolumn{2}{|c|}{ HWE } & $X^{2}=3.15^{*}$ & $X^{2}=0.07^{*}$ & $X^{2}=2.91^{*}$ \\
\hline
\end{tabular}

PsV, Psoriasis vulgaris; HWE, Hardy-Weinberg equilibrium; * not statistically significant, p $>0.05$ (3.84 is the $X^{2}$ threshold for statistical significance at the level $\mathrm{p}=0.05$ )

did not show significant difference between patients and controls, although A allele frequency was lower in patients with psoriasis and accordingly, A allele carriers, were underrepresented among patients with psoriasis. None of the 26 PsA patients was an A-allele carrier (Table 3). The frequencies of $\mathrm{G}$ and A alleles in subgroups of patients with early disease onset (psoriasis type 1) and late onset (psoriasis type 2) were similar, and did not reach the level of statistical significance compared to control subjects (data not shown).

When we stratified rs11465553 G and A allele carriers according to disease severity measured by PASI, we found no statistical significance between tested groups, although a trend toward higher percentage of A allele carriers $(\mathrm{p}=0.086)$ was observed in the group of patients with lower disease severity (Table 4).

Table 3. rs 11465553 allele, genotype and carrier counts and frequencies, along with statistical analysis of patients with PsV and PsA compared to healthy controls

\begin{tabular}{|c|c|c|c|c|c|c|c|c|c|c|c|}
\hline \multirow{2}{*}{$\begin{array}{c}\text { IL17F } \\
\text { rs11465553 }\end{array}$} & & \multicolumn{2}{|c|}{ Control } & \multicolumn{2}{|c|}{ PsV (total) } & \multicolumn{2}{|c|}{ PsA } & \multicolumn{2}{|c|}{ PsV (total) vs. controls } & \multicolumn{2}{|c|}{ PsA vs. controls } \\
\hline & & $\mathbf{n}$ & f & $\mathbf{n}$ & $\mathbf{f}$ & $\mathbf{n}$ & f & p & OR $(95 \% \mathrm{CI})$ & p & OR $(95 \% \mathrm{CI})$ \\
\hline \multirow{2}{*}{ Alleles } & $\mathrm{G}$ & 582 & 0,954 & 254 & 0,977 & 52 & 1,000 & \multirow{2}{*}{0,112} & $2,037(0,83-4,98)$ & \multirow{2}{*}{$0,157^{\dagger}$} & NA \\
\hline & A & 28 & 0,046 & 6 & 0,023 & 0 & 0,000 & & $0,491(0,20-1,20)$ & & NA \\
\hline \multirow{3}{*}{ Genotypes } & GG & 279 & 0,915 & 124 & 0,954 & 26 & 1,000 & 0,153 & $1,926(0,77-4,80)$ & $0,151^{\dagger}$ & NA \\
\hline & GA & 24 & 0,079 & 6 & 0,046 & 0 & 0,000 & 0,221 & $0,567(0,23-1,42)$ & $0,237^{\dagger}$ & NA \\
\hline & AA & 2 & 0,007 & 0 & 0,000 & 0 & 0,000 & $0,580^{\dagger}$ & NA & $1,000^{\dagger}$ & NA \\
\hline \multirow{2}{*}{ Carriers } & $\mathrm{G}$ & 303 & 0,993 & 130 & 1,000 & 26 & 1,000 & $0,580^{\dagger}$ & NA & $1,000^{\dagger}$ & NA \\
\hline & A & 26 & 0,085 & 6 & 0,046 & 0 & 0,000 & 0,153 & $0,519(0,21-1,29)$ & $0,151^{\dagger}$ & NA \\
\hline
\end{tabular}

PsV, psoriasis vulgaris; PsA, psoriatic arthritis; $n$, number; $f$, frequency; $p$, level of statistical significance; OR, odds ratio; CI confidence interval; ${ }^{\dagger}$ Fisher's exact probability test, NA, not applicable 
Table 4. rs11465553 carriers classified according to PASI

\begin{tabular}{|c|c|c|c|c|}
\hline IL17F rs11465553 & Low PASI & Moderate PASI & Severe PASI & $\mathrm{p}$ \\
\hline \multicolumn{5}{|l|}{ Carriers } \\
\hline $\mathrm{G}(\mathrm{GG}+\mathrm{GA})$ & $12(100.0 \%)$ & $63(100.0 \%)$ & $55(100.0 \%)$ & 1,000 \\
\hline $\mathrm{A}(\mathrm{GA}+\mathrm{AA})$ & $2(16.7 \%)$ & $3 \quad(4.8 \%)$ & $1 \quad(1.8 \%)$ & 0,086 \\
\hline
\end{tabular}

PASI, Psoriasis Area and Severity Index; G carrier, an individual with GG or GA genotype; A carrier, an individual with GA or AA genotype

\section{Discussion}

Our study is the first study demonstrating rs 11465553 G/A allele distribution in the third exon in IL17F gene, (corresponding to the position 534G/A in IL17F gene transcript and leading to Val 155 Ile substitution) in Serbian patients with PsV and healthy controls. A review of the available literature shows only two papers on rs11465553 distribution of alleles and genotypes. In Saudi Arabia, there was no association between rs11465553 and asthma susceptibility (12), while in South Korean patients rs11465553 was not associated with Behçet disease, another neutrophils mediated disease (13).

The main limitation of our study is the limited number of patients, precluding more general conclusions. Although in our study the frequency of A alleles was twice higher in controls than in patients with psoriasis, a small total number of A alleles resulted in failure to demonstrate significant differences in the distribution of alleles and genotypes between PsV patients and controls. A gradual decline of A allele frequency with the increase of PsV severity was also not statistically significant. Similarly, although we could not demonstrate presence of A allele in any of 26 patients with PsA, the difference was not statistically significant. However, these data may indicate that a study involving more PsV and PsA patients is warranted to demonstrate potentially protective effect of rs1 1465553 A allele in PsV and PsA.

Comparing the frequency of A allele in healthy Serbian, Saudi Arabian and South Korean population, we found that A allele is more frequent in Serbian population compared to both other populations.

Despite its limitations, our study is the first study that demonstrates distribution of ILITF
SNP rs11465553 in Serbian psoriasis patients and healthy controls. Also, our results are relevant because they represent the first report that reveals the allele and genotype distributions of rs11465553 single nucleotide polymorphism in one European population. Therefore, we believe that the results of this study will expand genetic knowledge considering the significance of ILITF polymorphisms in psoriasis that may prove valuable for future metaanalyses. Furthermore, this study will provide data for rs 11465553 alleles and genotypes distribution in healthy Serbian population, which may facilitate studies of this SNP in patients suffering from other diseases in Serbia and neighboring countries.

\section{Acknowledgment}

This study was supported by the Fund of The Serbian Ministry of Education and Science (Grant No. 175038).

\section{Abbreviations}

$\mathrm{PsV}$ - psoriasis vulgaris

PsA - psoriatic arthritis

PASI - Psoriasis Area and Severity Index

Th17 - interleukin-17 (IL17) - producing T cells 6p12 - short arm of the chromosome 6

EDTA - ethylenediamine tetra-acetic acid

SNPs - single nucleotide polymorphisms

Val - valine

Ile - isoleucine

\section{References}

1. Perera GK, Di Meglio P, Nestle FO. Psoriasis. Annu Rev Pathol 2012;7:385-422.

2. Gudjonsson JE, Karason A, Antonsdottir AA, Runarsdottir EH, Gulcher JR, Stefansson K, et al. HLA-Cw6-positive 
and HLA-Cw6-negative patients with psoriasis vulgaris have distinct clinical features. J Invest Dermatol 2002;118:362-5.

3. Naldi L. Scoring and monitoring the severity of psoriasis. What is the preferred method? What is the ideal method? Is PASI passe? Facts and controversies. Clin Dermatol 2010;28:67-72.

4. Schmitt J, Wozel G. The psoriasis area and severity index is the adequate criterion to define severity in chronic plaque-type psoriasis. Dermatology 2005;210:194-9.

5. Ariza ME, Williams MV, Wong HK. Targeting IL-17 in psoriasis: from cutaneous immunobiology to clinical application. Clin Immunol 2013;146:131-9.

6. Laggner U, Di Meglio P, Perera GK, Hundhausen C, Lacy KE, Ali N, et al. Identification of a novel proinflammatory human skin-homing Vgamma9Vdelta2 T cell subset with a potential role in psoriasis. J Immunol 2011;187:2783-93.

7. Kawaguchi M, Takahashi D, Hizawa N, Suzuki S, Matsukura S, Kokubu F, et al. IL-17F sequence variant (His161Arg) is associated with protection against asthma and antagonizes wild-type IL-17F activity. J Allergy Clin Immunol 2006;117:795-801.

8. Watanabe H, Kawaguchi M, Fujishima S, Ogura M, Matsukura S, Takeuchi H, et al. Functional characterization of IL-17F as a selective neutrophil attractant in psoriasis. J Invest Dermatol 2009;129:650-6.

9. Lin AM, Rubin CJ, Khandpur R, Wang JY, Riblett M, Yalavarthi S, et al. Mast cells and neutrophils release IL-17 through extracellular trap formation in psoriasis. J Immunol 2011;187:490-500.

10. Arisawa T, Tahara T, Shibata T, Nagasaka M, Nakamura M, Kamiya Y, et al. The influence of polymorphisms of interleukin$17 \mathrm{~A}$ and interleukin-17F genes on the susceptibility to ulcerative colitis. J Clin Immunol 2008;28:44-9.

11. Shibata S, Saeki H, Tsunemi Y, Kato T, Nakamura K, Kakinuma T, et al. IL-17F single nucleotide polymorphism is not associated with psoriasis vulgaris or atopic dermatitis in the Japanese population. J Dermatol Sci 2009;53:163-5.

12. Bazzi MD, Sultan MA, Al Tassan N, Alanazi M, Al-Amri A, Al-Hajjaj MS, et al. Interleukin 17A and $\mathrm{F}$ and asthma in Saudi Arabia: gene polymorphisms and protein levels. J Investig Allergol Clin Immunol 2011;21:551-5.

13. Jang WC, Nam YH, Ahn YC, Lee SH, Park SH, Choe JY, et al. Interleukin-17F gene polymorphisms in Korean patients with Behcet's disease. Rheumatol Int 2008;29:173-8.

\section{Polimorfizam interleukina $17 \mathrm{~F}$ gena- rs11465553 kod srpskih pacijenata sa psorijazom i zdravih osoba}

\section{Sažetak}

Uvod. Novija saznanja ukazuju na značaj proinflamatornih IL-17 citokina, u prvom redu IL17A i IL17F u patogenezi psorijaze. Ispitivali smo kod pacijenata sa vulgarnom psorijazom i kod zdravih osoba (dobrovoljni davaoci krvi) u Srbiji, polimorfizam pojedinačnog nukleotida koji se nalazi na $I L-17 F$ genu odgovornom za sintezu interleukin 17F. Ispitivali smo rs11465553 G/A polimorfizam koji se odnosi na supstituciju valina $(G)$ sa izoleucinom (A) na poziciji 155 na trećem eksonu gena $I L-17 F$.

Cilj ispitivanja se sastojao u određivanju učestalosti dva alela, G (valin) i A (izoleucin) ovog polimorfizma i distribucije njihovih genotipova kod pacijenata obolelih od vulgarne psorijaze i zdravih, kontrolnih osoba

Materijal imetode. Studijom je obuhvaćeno 130 pacijenta sa vulgarnom psorijazom lečenih na Klinici za dermatovenerologiju KCS i 305 zdravih davaoca krvi (materijal dobijen iz Zavoda za transfuziju krvi Srbije). DNK je izolovana iz periferne krvi a detekcija i analiza ispitivanog polimorfizma urađeni su TaqMan esejom za genotipizaciju (PE, Applied Biosystems Inc, Foster City, CA., USA.) sa Maxima Probe qPCR Master Mix-om (Fermentas Thermo Fisher Scientific Inc,
Vilnius, Lithuania) pomoću RealPlex²-a (Eppendorf AG, Hamburg, Germany), a prema preporukama proizvođača mešavine oligonukleotida.

Testirani uzorci bili su u Hardy-Weinberg ravnoteži a poređenje frekvencija alela između različitih grupa obavljano je $\chi^{2}$ testom ili Fišerovim testom tačne verovatnoće.

Rezultati. Urađena je analiza polimorfizma rs 11465553. Nije ustanovljena statistički značajna razlika u frekvenciji alela kao ni u frekvenciji genotipova između pacijenata obolelih od vulgarne psorijaze i zdravih kontrolnih osoba, iako je primećeno da je frekvencija A alela bila viša kod zdravih, kontrolnih osoba u odnosu na obolele odpsorijaze..

Diskusija. Naša studija je prva studija kojim je ustanovljena distribucija $\mathrm{G}$ i A alela u trećem eksonu gena za IL17F kod zdravih osoba i pacijenata sa vulgarnom psorijazom u Srbiji. U poređenju sa rezultatima drugih studija u kojima je analiziran ovaj polimorfizam, ustanovljeno je da je frekvencija A alela u zdravoj populaciji Srbije češća u odnosu na frekvenciju A alela u zdravim populacijama Koreje i Saudijske Arabije. 
Zaključak. Po prvi put je u Srbiji analiziran polimorfizam rs11465553. Rezultati naše studije predstavljaju istovremeno i prvu publikaciju u kojoj je sa aspekta polimorfizma pojedinačnih nukleotida, opisana distribucija alela i genotipova rs 11465553 polimorfizma u jednoj evropskoj populaciji. Odgovor na pitanje da li A alel ima protektivnu ulogu u odnosu na oboljevanje od psorijaze pružiće buduća istraživanja sprovedena na većem broju obolelih.

\section{Ključne reči}

Interleukin-17; Polimorfizam pojedinačnih nukleotida; Psorijaza; Psorijatični artritis; Davaoci krvi; Valin; Izoleucin; Lančana reakcija polimeraze u stvarnom vremenu 